A protoficção científica brasileira e sua hibridização através do fantástico: uma análise do conto "A sombra" de Coelho Neto | 409

\title{
A PROTOFICC̣ÃO CIENTÍFICA BRASILEIRA E SUA HIBRIDIZAÇÃO ATRAVÉS DO FANTÁSTICO: UMA ANÁLISE DO CONTO “A SOMBRA” DE COELHO NETO
}

\author{
BRAZILIAN PROTOSCIENCE FICTION AND ITS \\ HIBRIDIZATION THROUGH FANTASTIC: AN ANALYSIS OF \\ THE TALE "A SOMBRA" BY COELHO NETO
}

\author{
Thalita Ruth Sousa ${ }^{189}$ \\ Naiara Sales Araújo Santos ${ }^{190}$
}

RESUMO: A Protoficção Científica compreende obras produzidas antes da formação da Ficção Científica, mas que possuem fundamentos ligados ao desenvolvimento tecno científico. Caracterizada pelo hibridismo, a ProtoFC, por vezes, apresenta afinidades com outros gêneros. Este é o caso do conto A sombra (1927) do escritor Coelho Neto, que tem proximidades com o Fantástico. Nele, o personagem Avellar, um bacteriologista, mata a esposa Celúta através de um experimento com injeções de vírus e bacilos. Após o fato, ele é perseguido por uma sombra até que confessa o assassinato. Observa-se que a experiência científica provoca o medo do desconhecido, culminando num evento sobrenatural, rompendo com a realidade. A ciência, portanto, mostra-se falível e incapaz de fornecer explicações para tudo. Considerando as mudanças no cenário nacional devido ao progresso científico apregoado no início do século XX, objetiva-se analisar, por meio de pesquisa bibliográfica, a representação da ciência no conto A sombra (1927) e sua relação com a sociedade da época. A presente pesquisa visa também averiguar como a hibridização se constitui através do Fantástico na narrativa. Para tanto, são utilizados os apontamentos de Mary Del Priore (2014), Raul Fiker (1985), Isaac Asimov (1979) e David Roas (2018), entre outros.

${ }^{189}$ Mestranda pelo Programa de Pós-graduação em Letras da Universidade Federal do Maranhão - UFMA. Pesquisadora bolsista da Fundação de Amparo à Pesquisa e ao Desenvolvimento Científico e Tecnológico do Maranhão - FAPEMA.

${ }^{190}$ Doutora em Literatura Comparada. Professora do Programa de Pósgraduação em Letras da Universidade Federal do Maranhão - UFMA. 
Palavras chave: Protoficção Científica; fantástico; Coelho Neto.

ABSTRACT: Protoscience Fiction consists on literary works produced before the establishment of Science Fiction, but which fundamentals are related to the science and technology development. Due to its hibridism, the ProtoFC usually presents affinities with other genres. That is the case of the tale A Sombra (1927) by the writer Coelho neto, that has proximities with the Fantastic. In it, the charachter Avellar, a bacteriologist, kills his wife Celúta through an experiment with shots of virus and bacillus. After that, he is chased by a shadow until confessing the murder. The scientific experience provoques a fear of the unknown and generates a supernatural event which breaks the reality. Therefore, the science is portraited as flawed and uncapable of providing answer for everything. Considering the national scenario changes because of the scientific progress disseminated on the beggining of the twenth century, this work aims to analise, by means of bibliographical research, the representation of science in the tale A Sombra (1927) and its relationship with the society from that time. This research also aims to investigate how the Fantastic constitutes the hibridization of the narrative. For this purpose, the productions of Mary Del Priore (2014), Raul Fiker (1985), Isaac Asimov (1979) and David Roas (2018), among others.

Keywords: Protoscience Fiction; fantastic; Coelho Neto.

\section{Introdução}

A especulação sobre o mundo, motor criativo de Ficção Científica (doravante FC), pode ser traçada desde tempos primitivos. $\mathrm{O}$ instinto de questionar e a necessidade de encontrar respostas levaram o homem a construir conhecimento e narrar fantasias. A crítica do gênero associa essas narrativas a precursoras da FC, partindo de diversas perspectivas.

O crítico Lloyd Biggle (apud SCHOEREDER, 1986, p. 15) afirma que "uma simples brisa despertava uma interrogação, e o faiscar de um relâmpago constituía uma ameaça de condenação". Apesar do homem primitivo não conhecer a $\mathrm{FC}$, suas fantasias eram parte dela. Biggle acrescenta que "cada idade produziu uma 'ficção científica' que refletia a tecnologia e o pensamento científico dessa mesma idade". Contudo, a perspectiva de encontrar características de FC na antiguidade não é unânime. Há críticos que abordam como FC somente as obras que se enquadram na estética do gênero como ele foi concebido em tempos modernos. De acordo com o escritor Gilberto Schoereder, na obra Ficção 
A protoficção científica brasileira e sua hibridização através do fantástico: uma análise do conto "A sombra" de Coelho Neto | 411

científica (1986, p. 14), para alguns críticos a FC surgiu após a II Guerra Mundial, com poucas antecipações.

Ao comparar os dois pontos de vista apresentados anteriormente, é possível perceber que o posicionamento do homem primitivo se volta para o conteúdo geral da FC e o da modernidade "prende-se à forma pela qual a história é escrita” (idem). Ou seja, é levada em consideração a estética do gênero como se apresenta na atualidade. Há ainda os que consideram tais predecessores como pertencentes à Protoficção Científica, doravante ProtoFC, ponto de vista aqui adotado. Esse termo foi estabelecido por John Clute na obra Science fiction: the ilustrated encyclopedia (1994). A Protoficção Científica tem maior proximidade com a primeira concepção de FC aqui apresentada.

Segundo o escritor Raul Fiker, em Ficção científica: ficção, ciência ou uma épica da época? (1985, p. 25) a Protoficção Científica

se refere a manifestações, anteriores ao estabelecimento do gênero, de formas e tradições cujos temas e métodos foram posteriormente adotados pela FC. Por exemplo, o tema da viagem imaginária talvez seja o mais importante deles.

Portanto, observa-se a ProtoFC sob duas perspectivas: temporal, pois são obras que surgem antes da estruturação do gênero, e estético, já que elas apresentam afinidades com o que posteriormente será convencionado como FC. Assim, tais manifestações não tiveram base para fomentar o surgimento da FC, seja por não se originarem em um momento histórico e literário propício ao desenvolvimento tecnológico, seja pela estética de suas narrativas.

Como exemplo de ProtoFC, o pesquisador Roberto C. Belli em Ficção científica: um gênero para a ciência (2012), resgata um histórico que parte dos gregos:

Heródoto, o pai da História, nascido no século VIII a. C., falava em "homens metálicos" na Ilíada, contada depois por Homero, século V a. C., Plutarco de Queroneia (46125), no livro De Facie in Orbe Lunare ( $\mathrm{Na}$ superfície do disco lunar), descreveu seres mitológicos quer viviam na face da Lua. Provavelmente, Plutarco inspirou outros r, como Luciano de Samosata (125-180 d. C.) no livro Vera Historia (História Verdadeira), ao narrar uma interessantíssima 
disputa entre os seres da Lua e do Sol para colonizar Vênus. (idem, p. 22)

Tomando como destaque a Ilíada, é possível estabelecer conexão entre suas máquinas e aquilo que contemporaneamente se compreende como robô, por serem aparatos tecnológicos e terem constituição e comportamento semelhantes. Sendo assim, dentre as obras que constituem a ProtoFC, é possível encontrar desde mitos gregos a obras clássicas da literatura mundial. Em se tratando do conteúdo, o pesquisador André Monteiro no artigo "Teologia, Colonialismo e Ciência e Tecnologia/ensino na protoficção científica portuguesa (com ou sem política)" (2016, p. 3) diz que:

Quanto mais focado em ciência (ou algo que hoje consideramos ciência embora na altura pudesse ser "magia"), mais fácil é reivindicar como proto-fc, mas usando definições dalgum romance científico ou $\mathrm{fc}_{\mathrm{c}} \mathrm{do}$ fim do séc. XX podemos incluir na proto-fc algumas obras mais alegóricas, "raçadas" de fantástico e/ou promotoras de visões sociais.

Ou seja, mediante a estruturação do gênero, é possível perceber as obras que o prenunciaram. Todavia, quando elas foram publicadas, eram reconhecidas como constituídas de magia e geralmente arroladas ao gênero Fantástico. Isto se dá por trazerem o gênero em sua forma ainda embrionária em uma narrativa híbrida. Além do Fantástico, elas se entrelaçam com outras categorias literárias que também estavam em desenvolvimento, como a Utopia, o Horror, e o Gótico.

No contexto brasileiro, é possível observar obras que apresentam tais características, incluindo escritos de literatura maranhense. Dentre os autores que serão apontados no próximo tópico, é possível destacar Coelho Neto e seu conto "A Sombra", que está arrolado na coletânea Contos de vida e morte (1927), cujo título não deixa de ser prognóstico do enredo apresentado em suas narrativas. Nele, o bacteriologista Avellar mata sua mulher Celúta com aplicação de vírus e bacilos, mas responsabiliza a Ciência pelo assassinato. Até que ela definhe, ele a vê como uma experiência fascinante que provoca medo por ser "incubadora da morte". A partir do funeral, uma sombra o persegue, até que ele confessa o crime. 
A protoficção científica brasileira e sua hibridização através do fantástico: uma análise do conto "A sombra" de Coelho Neto | 413

Considerando as figurações presentes na narrativa, objetiva-se analisar a relação entre a ProtoFC e o Fantástico em "A sombra", observando suas implicações na formação do enredo. Além disso, investiga-se como o desenvolvimento científico ocorrido no início do século XX é refletido na visão da Ciência presente no conto de Coelho Neto. Para tanto, os procedimentos metodológicos se baseiam em pesquisa bibliográfica qualitativa e análise de conteúdo.

\section{$2 \mathrm{O}$ desenvolvimento científico e sua influência na literatura}

A busca por uma explicação racional dos fenômenos relativos à humanidade e ao mundo natural era apregoada no século XIX, assim como fora desde o início do século das luzes, o XVIII. As concepções voltadas para o fortalecimento da ciência em detrimento do misticismo e das crenças religiosas opositoras eram reforçadas por pensadores e críticos europeus. A historiadora Mary Del Priore analisa a sociedade do século XIX e estabelece divergências com o pensamento dos séculos anteriores na obra Do outro lado: a história do sobrenatural e do espiritismo (2014). Segundo ela, neste século havia a crença de que a ciência era superior e que

só a razão afastaria os homens de toda a superstição e os curaria da atração que os mistérios exerciam. Era preciso deixar para trás o que consideravam "as trevas da Idade Média". Apenas a ignorância, o fanatismo, o medo ou o ódio justificariam a "fraqueza" de crer no sobrenatural. (idem, p. 19)

Nesta mesma perspectiva, o crítico David Roas em Behind the frontiers of the real: a definition of the fantastic (2018, p. 5) analisa que no século XVIII a sociedade baseava suas explicações para o real na ciência, religião e superstição. Ele afirma que "fantasmas, milagres, elfos e outros fenômenos sobrenaturais eram parte da concepção de real. Eles eram extraordinários, mas não impossíveis ${ }^{191 " ~[t r a d u c ̧ a ̃ o ~ n o s s a] . ~ N e s t e ~ c e n a ́ r i o ~}$ decorrente do Iluminismo, o sobrenatural buscava ser superado pela ciência por meio de leis racionais.

${ }^{191}$ Ghosts, miracles, elves and other supernatural phenomena were part of the conception of the real. They were extraordinary, but not impossible. 
Foi nesse contexto que o Fantástico surgiu, trazendo o metafísico para a literatura. A esse respeito Adriano Messias em Todos os monstros da terra: bestiários do cinema e da literatura (2016, p. 24) interpreta que o Fantástico se originou "a partir da rejeição do Iluminismo para com o pensamento teológico medieval e toda sua metafísica. Dessa maneira, [...] o fantástico teria exercido a função de fraturar um excesso de racionalidade na cultura". Em outras palavras, aquilo que o racionalismo antropocêntrico buscava deslocar para a margem dos estudos foi resgatado pela literatura fantástica.

O sobrenatural que antes compunha uma das formas de explicação do universo comumente aceito, como já posto por Roas, firmava-se nas formas artísticas. Ao tratar da sociedade que recepcionou este gênero, Roas explica que a "literatura fantástica nasceu em um universo mecânico Newtoniano, concebido como uma máquina que obedecia às leis da lógica e era sujeito à explicação racional ${ }^{192 " ~[t r a d u c ̧ a ̃ o ~}$ nossa] (2018, p. 5). Observa-se, assim, a posição de contraponto que o fantástico estabelece em relação ao pensamento científico. A proximidade com a ciência não estava somente atrelada aos estudiosos, mas também à população. Isso se dava devido às descobertas científicas e aos produtos tecnológicos que modificaram as formas de transporte e trabalho, por exemplo.

Concordando com o pensamento da historiadora Del Priore e dos críticos do fantástico Messias (2016) e Roas (2018), o crítico de FC Isaac Asimov e o pesquisador Edgar Smaniotto também afirmam a relevância do século XIX para a ciência. Contudo, enquanto o Fantástico se preocupava em expor o metafísico, o gênero Ficção Científica nascia com o propósito de trazer as concepções racionais para o âmbito da literatura.

Em um artigo para a Asimov's SF Adventure Magazine chamado "The pre-scientific universe" $(1979$, p. 6), Asimov explica que a FC não poderia existir como imagem do futuro até que as pessoas entendessem que ciência e tecnologia produzem o futuro. Acrescenta ainda que a Revolução Industrial, no século 1800, possibilitou esse entendimento, visto que as mudanças científicas e tecnológicas foram expressivas a ponto de serem notadas no curso de vida das pessoas.

192 Literature of the fantastic was born into a Newtonian, mechanical universe, conceived as a machine that obeyed the laws of logic and was therefore subject to rational explanation. 
A protoficção científica brasileira e sua hibridização através do fantástico: uma análise do conto "A sombra" de Coelho Neto | 415

Nesse sentido, a especulação e criação baseadas em métodos científicos passaram a caracterizar a estética do gênero. Ratificando este pensamento, Smaniotto (2012, p. 29) evidencia que a explicação era "dentro do escopo dos saberes científicos socialmente aceitos na época da sua produção" e isso favoreceu o surgimento da FC. De acordo com a perspectiva acima exposta, Asimov (1984, p. 17) considera como o marco inicial da literatura de FC a obra Frankenstein (1818) de Mary Shelley (1818), ponto de vista adotado na presente pesquisa. Esta obra narra a história do Dr. Frankenstein, cientista que cria um ser a partir de pedaços de corpos humanos, através da eletricidade.

Mediante o cenário histórico e ideológico relativo à ciência e sua disseminação na sociedade apresentado no decorrer deste capítulo, é possivel compreender por que somente no século XIX a literatura de FC se apresenta na Europa. É perceptível que, se comparada a países com séculos de desenvolvimento tecnológico como a Inglaterra, a produção brasileira parecerá pálida. Não obstante, apesar de não serem suficientes a ponto de aproximarem o pensamento científico da sociedade em geral, houve manifestações advindas de pesquisas científicas que resultaram em produtos tecnológicos brasileiros.

\section{A Protoficção Científica Brasileira}

O livro Prelúdio para uma história: ciência e tecnologia no Brasil (2004), organizado pelo historiador Shozo Motoyama, objetiva resgatar a produção científica e tecnológica nacional desde o Brasil colônia, mas, sobretudo, desde a chegada da família real portuguesa em 1808. Por outro lado, apresenta também as razões para tais avanços serem mais pontuais e como a cultura influenciou esse desenvolvimento.

A partir de sua análise, compreende-se como a ciência no Brasil era observada de modo diferente se compararmos ao que ocorria nesses mesmos períodos na Europa. Na introdução Ciência e tecnologia no Brasil para onde?, ele explica:

[...] Criada e plasmada dentro de uma tradição colonial e de dependência, agravada pela economia baseada no regime escravocrata, a cultura brasileira moldou-se no âmbito do retórico e do literário, não se ocupando muito das coisas de C\&T [Ciência e Tecnologia]. Já que o trabalho e a técnica eram atribuições de escravos, a elite nacional desprezava as atividades manuais. Em 
consequência, não se sentia atraída pela experimentação, chave mestra da ciência, e ficava pouco à vontade frente às questões tecnológicas. Contudo, isso não significa que não tenha havido em nossas terras manifestações brilhantes de aptidão técnica e gênio científico. Para constatar esse ponto, basta ver os trabalhos do padre Bartolomeu e Gusmão inventando o aeróstato no século XVIII, de José Bonifácio de Andrada e Silva realizando investigações reconhecidas internacionalmente na área de mineralogia no século XIX, do padre Roberto Landell de Moura patenteando o rádio no alvorecer do século XX, só para citar alguns nomes. (idem, p. 18)

Portanto, à luz de Motoyama, tratar o desenvolvimento científico e tecnológico no Brasil como inexistente ou insignificante seria até mesmo preconceito, advindo de ignorância a respeito do material aqui produzido. Nesta mesma obra a pesquisadora Marilda Nagamini expõe sua pesquisa em dois capítulos, nos quais traça o desenvolvimento Científico e Tecnológico do século XIX ao XX.

Em se tratando do início século XIX, ela explica no capítulo 1808 1889: ciência e técnica na trilha da liberdade que os esforços pela implementação da Ciência no país se concentraram nas áreas da Medicina, Química, Farmácia, Botânica, Matemática e Física, entre outros. Ao longo desse século, tais investimentos se estenderam para Artes, Engenharia, Geografia e Direito, por exemplo. De 1889 até 1930, Nagamini mostra como os processos de urbanização e industrialização se instalaram, aprofundando os investimentos em áreas como Aviação, Indústria Cafeeira e Ferroviária, Mineração e Metalurgia (2004, pp. 137183).

Dessa forma, enquanto a Europa sentia os reflexos dos avanços científicos que proporcionaram o Iluminismo e a Revolução Industrial na vida diária, já no início do século XIX, o Brasil ainda se apoiava principalmente na agroexportação de produtos como café, algodão e borracha advindos da exploração de mão de obra escrava.

A independência do país ocorrera no início do século, em 1822, e a abolição da escravatura no fim deste, com a Lei Áurea em 1888. A impressão deixada pela colonização europeia ainda era recente para a nação, que a partir do final do século XIX tentava estabelecer sua identidade. Apesar de buscar moldes europeus da Belle Époque, as artes nacionais buscavam retratar os símbolos nacionais como a natureza. 
A protoficção científica brasileira e sua hibridização através do fantástico: uma análise do conto "A sombra" de Coelho Neto | 417

Portanto, neste cenário, a figura da ciência poderia não ser vista como representante de nacionalidades, mas como um elemento externo. Além disso, as ideias de progresso importadas da Europa não só geraram anseios de transformação, mas também conflito social.

Segundo Del Priore, "havia uma face sombria nesse período". Ela afirma que a inflação, o desemprego e a superprodução de café formaram a crise econômica da época da República. Isto, somado "à concentração de terras e à ausência de um sistema escolar abrangente, fez com que a maioria dos escravos recém-libertos passasse a viver em estado de quase completo abandono” (2014, p. 113). Portanto, a ausência de condições básicas de vida era marcante nesse período, contrastando com o progresso pregado pela elite. Logo essa situação social passou a figurar como temática na literatura. Ainda segundo Del Priore, alguns autores que antes se dedicavam à busca pela identidade nacional passaram a focar no "temor do progresso e da ciência" (idem, p. 144).

Outro fator que levou a sociedade a refletir sobre os benefícios e malefícios do desenvolvimento científico foram as políticas sanitárias aplicadas no período. No início do século XX, doenças como varíola e febre amarela foram protagonistas de epidemias e passaram a ser estudadas, o que colocou profissionais como bacteriologistas e médicos em destaque.

Devido à proliferação dessas enfermidades, o governo tomou medidas, como a obrigatoriedade da vacina, fato que gerou A Revolta da Vacina em 1904. O caos público se instaurou devido ao modo como a medida foi aplicada. Segundo o historiador Nicolau Sevcenko, na obra A revolta da vacina (2014, p. 10), o regulamento rígido abrangia todas as idades, "impondo vacinações, exames e reexames, ameaçando com multas pesadas e demissões sumárias, limitando os espaços para recursos, defesas e omissões”. Ainda segundo Sevcenko, o objetivo era ter uma campanha rápida e efetiva, sem "preocupação com a preparação psicológica da população, de quem só se exigia submissão incondicional” (idem). Consequentemente, é possível inferir que o olhar da população sobre a ciência não foi favorecido, pois

a pobreza estava em toda a parte, e as grandes reformas urbanas que tentavam transformar o Rio de Janeiro em Paris não abafavam certo mal-estar de viver. As mudanças políticas não atingiram a sociedade toda. Só as elites se beneficiaram. Mas não foram apenas as frustrações de 
ordem política que modelaram a vida cotidiana. A modernidade dos bondes, da luz elétrica e do telefone trazia também uma resistência às mudanças. Vivia-se o que um historiador denominou de "a revolta contra a razão". Em revanche, recorria-se ao fantástico e ao imaginário popular, recheado de fadas, demônios e aparições. A literatura escapista transportava para outro mundo, onde o sobrenatural dava as cartas. Nele, nada causava espanto ou surpresa. Tudo era possível! (DEL PRIORE, 2014, p. 113)

Entende-se, desse modo, que além de conduzir à especulação acerca dos caminhos que a ciência propiciaria ao homem, a literatura abarcava também o sobrenatural que fugia daquela realidade revoltante. Com isso, é possível compreender a existência de obras nesse período que trouxessem elementos referentes à literatura de FC e à literatura Fantástica. Havia uma busca por registrar as impressões da ciência no Brasil, seja demonstrando seu lado negativo, seja a superando por intermédio do sobrenatural.

Se levado em consideração que a FC no país ganhou destaque em meados do século XX, e que críticos como Schoereder apontam Três meses no século 81 (1947) de Gerônimo Monteiro como a primeira obra de FC (1986, p. 22), é válido afirmar que as obras criadas no final do século XIX e início do século XX foram precursoras da ProtoFC no Brasil. Contudo, o contexto e o desenvolvimento da FC no Brasil levam a crer que os autores de ProtoFC não tinham conhecimento da estrutura do gênero. Concordando com isto, o historiador Francisco Skorupa explicita em Viagem às letras do futuro: extratos de bordo da ficção científica brasileira: 1947. 1975 (2001, p. 53) que

os autores estrangeiros e brasileiros que escreveram suas impressões imaginadas a respeito do "choque" com a ciência, principalmente, entre a metade do século XIX e as três primeiras décadas do $\mathrm{XX}$, o fizeram sem ter a consciência exata do nascimento da nova forma literária, até mesmo pela própria indefinição na denominação do que estava sendo feito. Romance científico, antecipação, vulgarização científica, romance didático, ciencificção e enfim ficção científica, demonstram as incertezas em afirmar o que eram tais escritos. Somente nos anos 1930 o termo atual e definitivo de Ficção Científica firmou-se 
A protoficção científica brasileira e sua hibridização através do fantástico: uma análise do conto "A sombra" de Coelho Neto | 419 como denominação aglutinante e referencial para o gênero. Até mesmo a França, berço da "antecipação”, o incorporou de modo que fosse possível falar, a partir daí, em uma consciência de gênero. Há, portanto, uma diferença entre os que faziam ficção científica utilizando as noções próprias do mundo cientificizado e aqueles que fazem a mesma coisa cientes da existência de um gênero literário específico para esses escritos.

Dessa forma, a produção nacional partia da realidade e enveredava pela fantasia, utilizando-se de diversos elementos e recursos literários, apesar de estes não serem reconhecidos como parte do gênero FC. Trazendo uma memória pessoal, Allen retrata que nas décadas de 30-40 as revistas X-9 e Detective, que abordavam contos policiais e incluíam histórias de FC, e Cold air, de Lovecraft, já eram publicadas em território nacional. Concordando com Skorupa, Allen afirma que nesta época as criações ainda não eram reconhecidas como FC, mas este discorda no que concerne à fixação do termo "ficção científica" em território nacional: segundo ele, isto só ocorrera no fim da década de 50; ao mesmo tempo em que as nomenclaturas ciência-ficção e science-fiction ainda eram utilizadas (ALLEN, 1974, pp. 4-5).

Notam-se elementos que caracterizariam o que posteriormente seria denominado FC na obra dos escritores Joaquim Felício dos Santos e Emílio Zaluar, como afirma a crítica Naiara Araújo (2017) em "Ficção científica brasileira: ecofeminismo e pós-colonialismo em Umbra de Plínio Cabral" ao comentar o trabalho da pesquisadora Yolanda MolinaGavilan:

Segundo Yolanda Molina-Gavilan em seu Chronology of Latin American Science Fiction, 1715-2005 (2007), em meados do século XIX autores brasileiros começaram a escrever contos sobre sociedades imaginárias e viagens ao futuro, nos moldes de Júlio Verne e Camille Flammarion. Estes trabalhos descritivos tratavam principalmente sobre reformas políticas através da representação de eventos ou sociedades futuras, como em Páginas da História do Brasil (1868-1872) de Joaquim Felício dos Santos e O Doutor Benignus (1875) de Emílio Zaluar. (ARAÚJO, 2017, p. 2) 
O supracitado escritor Emílio Zaular fora, por exemplo, inspirado pelo renomado escritor de FC francesa Júlio Verne, ao escrever $\mathrm{O}$ doutor Benignus (BELLI, 2012, p. 63). Observa-se que autores de FC consagrados pela crítica exerceram influência sobre alguns autores brasileiros, fomentando a especulação sobre o desenvolvimento da ciência e tecnologia. Das obras escritas a partir do início do século XX, Silva destaca, entre outras, Esfinge (1906), do maranhense Coelho Neto, A era do automóvel, A fome negra e O dia de um homem em 1920 (1911), do carioca João do Rio, O reino de kiato (1922), do baiano Rodolpho Theophilo, A Amazônia misteriosa (1925), do também carioca Gastão Cruls, o polêmico O presidente negro/O choque das raças (1926), do paulista Monteiro Lobato, mais conhecido por sua literatura infanto-juvenil, e Sua Excia. a presidente da república no ano 2500 (1929), da também paulistana Adalzira Bittencourt.

No que tange à literatura maranhense, além de Coelho Neto com o livro Esfinge e o conto "A sombra", é possível listar também outros autores. Aluísio Azevedo com seu conto "Demônios" de 1893, no qual os protagonistas sofrem uma involução que remete à teoria Darwiniana; além de Humberto de Campos com figuras médicas nos contos "Os olhos que comiam carne”, no qual se apresenta uma máquina de raio-x, e "Morfina”, que traz a droga análoga ao título, sendo ambos de 1934.

\section{A ProtoFC e a hibridização através do Fantástico em "A Sombra" (1927)}

A vastidão da obra de Coelho Neto e sua diversidade são motivo de controvérsia entre aqueles que apreciam sua escrita ou o criticam por isso. Nas palavras do crítico Alexander Silva (2008, p. 88), "as opiniões conflitantes de contemporâneos e de historiadores da literatura sobre Coelho Neto exemplificam a dificuldade, ainda presente, de se definir o status do escritor dentro do cenário da literatura Brasileira". Essa indefinição não diminui sua riqueza literária, pelo contrário, uma vez que é possível observar características tanto de movimentos literários como Romantismo e Realismo, quanto de gêneros marginalizados no Brasil, mas em desenvolvimento na Europa, como o Gótico e a FC. Isso demonstra uma sensibilidade e perspicácia do autor quanto às possibilidades literárias que ele dispunha para retratar em suas obras as ideologias que permeavam o imaginário social brasileiro.

Coelho Neto, nascido no Maranhão, morou no Rio de Janeiro na virada do século XIX-XX e testemunhou fatos históricos positivos e 
A protoficção científica brasileira e sua hibridização através do fantástico: uma análise do conto "A sombra" de Coelho Neto | 421 negativos relativos ao progresso científico. Dentre eles podemos ressaltar, respectivamente, a Belle Époque tropical, com toda sua perspectiva de prosperidade, e a Primeira Guerra Mundial (1914-1918), que trouxe instabilidade econômica e política, como aborda a pesquisadora Márcia Gonçalves em O Rio de Janeiro de Coelho Neto: do império à república (2016, p. 23). A autora adiciona ainda acontecimentos como a "Revolução Russa de 1917, o imperialismo e a luta de classes" (idem). A tais acontecimentos que estão em menor ou maior grau ligados ao desenvolvimento científico, é possível adicionar um que será imprescindível para a leitura do social em "A sombra": A Revolta da Vacina ocorrida no Rio de Janeiro em 1904 e referida no capítulo anterior.

$\mathrm{O}$ início do conto aqui analisado apresenta uma pessoa escandalizada em ver uma notícia de jornal, na qual seu amigo médico Avellar confessa ser assassino da esposa Celúta. Após a leitura, ele pondera que aquilo só seria possível se seu amigo estivesse louco, levantando uma hipótese que mais à frente é enfatizada. Das reflexões desta personagem, é possível extrair que o diagnóstico da morte da esposa fora septicemia aguda, que se constitui como uma infecção generalizada, disseminada através da corrente sanguínea, e cujos agentes são vírus, fungos e bactérias. Tentando entender o que levou Avellar a esta confissão, este amigo não nominado se dirige até o Quartel da Brigada, onde o médico, devido a seu título, estava preso. Daí, infere-se a condição de prestígio que Avellar ocupava dada sua profissão.

Quando indagado das razões para ter matado a esposa, ele traz primeiro o ciúme, a suspeita, fazendo alusão a "micróbios no mundo moral" e "palavras vagas que nos entram n'alma e lá se desenvolvem e proliferam em desconfianças” (COELHO NETO, 1926, p. 202). Ele adiciona: "Ciência... uma história! Tudo falha. Nada se pode afirmar, nada! E, queres que te diga? A mais culpada em tudo isso foi a Ciência. Foi ela que me levou ao crime, porque o ciúme... O ciúme... Não havia motivo para ciúme. Celúta era honesta”. (COELHO NETO, 1926, p. 203)

A culpa que Avellar transfere para a ciência revela tanto seu desgosto com aquela que propiciou sua profissão, quanto desconfiança em relação à própria credibilidade da ciência, uma vez que nela há falhas (o que remonta aos experimentos científicos) e, em consequência, não se obtém dela conclusões plausíveis. Há uma desconfiança que confronta a visão da Ciência como esperança de desenvolvimento e reforça o ponto de vista da Ciência como uma agente contra o ser humano. Esta 
perspectiva da Ciência como maléfica, introduz a ideia de que nem sempre a ciência traz resultados que beneficiam o homem. Recorrentemente seus produtos são utilizados de forma errônea ou deturpada, ou mesmo suas pesquisas visam propósitos ilícitos. Como explica o crítico e escritor Bráulio Tavares em $\mathrm{O}$ que é ficção científica? (1986, pp. 19-20), "existe uma face tenebrosa".

A fim de expor e justificar sua afirmação, o autor aponta catástrofes, desde a invenção da pólvora até o final do século XX, que foram provocadas pelo uso indevido da ciência, de modo que a visão desta como meio para alcançar o progresso humano ficou manchada em vários períodos da história. No caso do início do século XX, o mais notável exemplo mundial é a I Grande Guerra. As imagens do médico cientista e da ciência como vilãs são aprofundadas no conto, como se pode observar conforme ele prossegue: Avellar admite ter envenenado a esposa, o que se deu após várias tentativas. Ao descrever seu método para o homicídio, é possível perceber a ignorância do médico em relação ao uso de doses de bacilos da tuberculose e outros germes, a saber:

Matei-a com bacilos da tuberculose, esses e outros germes letais. Propinando-lhe as primeiras doses, inoculadas em frutos - (tratava-se, então, da vingança da minha honra... Pobre Celúta!) esperei as manifestações do mal e... nada! Em vez do deperecimento, dos sinais característicos da ação destrutiva do bacilo de Koch, o que eu via, e todos o apregoavam em louvores, era o reviçamento da vítima, mais robustez, aspecto magnífico, apetite, sono tranquilo, higidez absoluta. A própria enxaqueca que, de vez em quando, a atormentava, desapareceu. (COELHO NETO, 1926, p. 203)

Em razão do médico referir-se à mulher como "Pobre Celúta!" e "vítima" (COELHO NETO, 1926, p. 203), nota-se que, de forma contraditória, Avellar aplica doses que ele acredita poder matar, mas ao mesmo tempo tem piedade de Celúta. Esse contraponto é evidenciado à medida que Avellar se divide entre o marido e bacteriologista. Ele culpa o último pelas suas ações: "Não foi o marido o assassino, foi o bacteriologista, o homem de ciência, o prático de laboratório, entendes? $\mathrm{O}$ profissional que não podia compreender que um organismo, frágil como o de Celúta, resistisse ao ataque insistente de tantos vibriões" (idem, pp. 203-204). O fato de Celúta ter elementos "mortíferos" e 
A protoficção científica brasileira e sua hibridização através do fantástico: uma análise do conto "A sombra" de Coelho Neto | 423

"violentos" (idem) em seu corpo e não padecer pasma Avellar, pois ele não consegue compreender.

Neste trecho, observa-se que Avellar refere a si mesmo como dois: o marido e o bacteriologista, sendo o segundo o "homem da ciência". Este posicionamento remete ao Duplo, fenômeno estudado pela psicanálise. A presença desta figuração que não ocorre devido à ciência demonstra a hibridização que a narrativa de ProtoFC apresenta. É possível interpretar por meio do comportamento de Celúta que as injeções, ao invés de causar mal, agiram com o mesmo efeito de uma vacina, apesar do método de aplicação utilizado ser diferente. Não foi considerada pelo bacteriologista a ideia de que a injeção poderia fazer bem à vítima, pois como poderia algo proveniente de germes letais beneficiar o homem? Compreende-se que o conhecimento acerca do uso de injeções não era domínio de Avellar, ou que esse conhecimento ainda não fora descoberto. Mediante os estudos proporcionados pelo avanço da biomedicina, entende-se que injeções, uma vez utilizadas para injetar uma preparação biológica com o fim de conferir imunidade, são positivas, pois são vacinas.

Tal fato alude ao desconhecimento que a maioria da população brasileira tinha da ciência do século XX, um dos fatores para a Revolta da Vacina. Como já exposto no capítulo anterior, não houve preparação psicológica ou educacional da população sobre a constituição da vacina. Dessa forma, seus benefícios eram desconhecidos e o medo de que o conteúdo dela culminasse na morte do indivíduo que a recebera se propagou. Exemplo dito é a fala do político Rui Barbosa exposta por Sevcenko:

Não tem nome, na categoria dos crimes do poder, a temeridade, a violência, a tirania a que ele se aventura, expondo-se, voluntariamente, obstinadamente, a me envenenar, com a introdução no meu sangue, de um vírus sobre cuja influência existem os mais bem fundados receios de que seja condutor da moléstia ou da morte. $(2014$, p. 8)

A afirmação, advinda de uma figura pública de poder político, representa o quanto a vacina ainda era desconhecida no cenário nacional. O medo, somado ao modo de aplicação do recurso, aumentou a apreensão da população, e uma vez que fora o produto da ciência que favoreceu a perturbação, gerou-se mais desconfiança nela. Essa impressão 
da ciência reverbera no imaginário da população nas primeiras décadas, de modo que se reflete na literatura.

É cabível expressar que ambos os fatores são encontrados em "A Sombra", evidenciados na ignorância de Avellar, tanto em utilizar bacilos e vírus como armas da maneira como fez, quanto em relação às reações provocadas no sistema imunológico de Celúta. Alexander Silva analisa este conto também por uma perspectiva fantástica.

Segundo Silva, "o elemento fantástico do conto está no fato de que, ao contrário do que Avellar esperava, ou seja, uma morte rápida provocada por bacilos de tuberculose inoculados em frutos, Celúta se tornava cada vez mais vigorosa" (idem, pp. 100-101). Seguida a lógica da narrativa, entende-se que há um rompimento na ordem dentro do conto, pois esse fato é tomado com espanto por Avellar. Esta outra perspectiva de leitura é abordada também por Del Priore. A historiadora considera sobrenatural o fato de que, "ao contrário de morrer rapidamente, inoculada que fora com bacilos da tuberculose, Celúta se tornava mais e mais vigorosa" (2014, p. 114). Portanto, observa-se que a falta de conhecimento ao fazer uso da ciência levou a um acontecimento sobrenatural, que até o final da narrativa não é explicado.

Tal fato perturba Avellar, pois rompe com suas crenças. Levando em conta a perspectiva da incerteza, é possível associar essa cena com a concepção de Fantástico proposta por Tzvetan Todorov no clássico teórico Introdução à literatura fantástica (1975, p. 31): "O fantástico é a hesitação experimentada por um ser que só conhece as leis naturais, face a um acontecimento aparentemente sobrenatural". Portanto, "A sombra" tem aproximações com o gênero Fantástico, paradoxalmente propiciadas pela visão de ciência na obra.

O "homem da ciência" faz da frustração mediante à reação biológica positiva um combustível para continuar sua experiência e testar o limite do corpo humano, tornando Celúta sua experiência. Para ele, ter lançado mão de todo seu arsenal e vê-la bem era enlouquecedor (idem, $\mathrm{p}$. 204). O fato de Avellar aplicar injeções com bacilos e vírus em sua mulher remete a uma discussão relevante para a ciência do início do século XX: a violação do corpo humano justificada por uma razão científica, apesar das motivações serem diferentes em ambas as situações.

Ao fazer referência às pesquisas sobre a transmissão da febre amarela, Ilana Löwy em Virus, mosquitos e modernidade (2006, p. 75) expõe a justificativa dos pesquisadores da época: "O homem parecia ser o único hospedeiro possível, o que, segundo eles, legitimava a necessidade de fazer experimentos em seres humano [...]". Tal tópico abre questionamentos 
A protoficção científica brasileira e sua hibridização através do fantástico: uma análise do conto "A sombra" de Coelho Neto | 425 para o limite do fazer científico e da busca humana por respostas. Isto demonstra também o avanço das pesquisas em âmbito nacional na área de microbiologia. Segundo Maria Dantes, em As ciências na história brasileira (2005), a pesquisa biomédica nacional teve relevante fomento no período de transição entre os séculos XIX e XX, mas ainda era considerada uma "nova maneira de fazer ciência":

[...] O primeiro serviço sanitário do período republicano foi o de São Paulo, de 1892, composto por um conjunto de instituições que seguiam os princípios da nova teoria microbiológica. Já a Diretoria de Saúde Pública do Rio de Janeiro começou a atuar em 1900. Essas instituições de pesquisa biomédica dedicavam-se às seguintes atividades: estudos sobre as principais doenças encontráveis no país, diagnóstico de doenças em evidência e produção de soros e vacinas para seu combate. E aí, os médicos brasileiros foram bastante pioneiros, acompanhando de perto o que acontecia em centros europeus. Esses institutos ganharam prestígio no meio científico brasileiro, como introdutores de uma nova maneira de fazer ciência: a ciência de laboratório, vista como um contraponto à tradição naturalista, considerada mais tradicional. (DANTES, 2005, p. 28)

Por conseguinte, as inovações no campo da pesquisa em biomedicina ainda estavam sendo introduzidas para o meio acadêmico, mas como exposto anteriormente ao tratar da Revolta da Vacina, para a população este conhecimento não era acessível. Em relação ao conto, isso é percebido na forma em que a ciência de laboratório carece de procedimentos e compreensão dos devidos métodos científicos a serem empregados.

Em continuidade, após ver que a esposa está mais saudável ao invés de padecer, Avellar começa a temê-la. A narrativa não faz alusão à receptividade de Celúta para com tais injeções, somente narra que Celúta se tornou mais afetiva ao perceber a mudança de comportamento em Avellar. Agora ele a vê como um receptáculo de vírus e tem medo dela lhe transmitir a morte mesmo com um toque (COELHO NETO, 1926, p. 204). O médico passa a não ver mais a esposa, mas sim uma "incubadora, de morte, uma figura sinistra que encarnava todas as pestes, não lhes 
sofrendo as consequências, como as serpentes não se envenenam com a peçonha" (idem). Sendo assim, as reações das injeções no corpo de Celúta eram desconhecidas para Avellar e a transformaram, aos olhos dele, numa espécie de monstro.

É relevante ressaltar que Celúta como a personificação da morte e assumindo a figura do monstro, remetem às histórias góticas. Ratificando isto, Silva (2008, p. 101) afirma que Avellar a vê da mesma forma que era vista a mulher na literatura gótica, de forma geral como a personificação da morte. Esse entrelace presente no conto ressalta sua característica de narrativa híbrida. Tavares afirma que "a ciência é o triunfo do conhecido sobre o desconhecido" (1986, p. 17); contudo, tal triunfo advém do enfrentamento dos limites já conhecidos pelo homem. A confrontação, por sua vez, gera receios e medo, pois, como afirma o escritor e crítico $\mathrm{H}$. P. Lovecraft na obra O horror sobrenatural na literatura (1987, p. 1): “A emoção mais forte e mais antiga do homem é o medo, e a espécie mais forte e mais antiga de medo é o medo do desconhecido".

Além disto, não só o desconhecido em si provoca temor, mas também o que provém dele, por não ser familiar. $\mathrm{O}$ desconhecido se prova um desafio para o ser humano, um que ele não tem a certeza de vencer ou dominar, por não saber o que deve ser feito em um enfrentamento ou, no caso mais aterrador, o que será enfrentado. Por ser ao mesmo tempo onipotente e terrível, o desconhecido se tornou para alguns algo a ser temido e, para outros, algo a ser desbravado. Primeiramente, Avellar temia a figura assombrosa que Celúta se tornara para ele, contudo, o médico deseja agora dominar o conhecimento da situação através da experimentação, desbravando o desconhecido:

O marido desapareceu ficando apenas o observador apaixonado por uma experiência. E, encerrando-me no meu laboratório horas e horas, dias e dias, eu estudava aquele caso estranho, fenômeno, sem dúvida, mais belo do que a fagocitose, porque era a luta tremenda de germes letais, uma batalha formidável de legiões pestíferas no organismo débil de uma mulher. (COELHO NETO, 1926, p. 204)

A princípio, os propósitos dele eram assassinos, mas agora o fascínio pela experiência laboratorial se sobrepõe e beira à loucura. Avellar só tenta intervir depois que Celúta morre, ou seja, quando a experiência tem fim. O cientista de "A Sombra" não tem preocupação 
A protoficção científica brasileira e sua hibridização através do fantástico: uma análise do conto "A sombra" de Coelho Neto | 427

com a ética em sua pesquisa, demonstrando ausência de afetividade ao separar o "marido" do "observador apaixonado", de modo que o valor de contemplar a batalha biológica é superior ao de manter a esposa com vida.

Em FC, a figuração que ele assume é referida como o cientista louco. A figura do cientista como um louco que ultrapassa limites éticos é recorrente na literatura de $\mathrm{FC}$ e remete à primeira obra do gênero, Frankenstein. O Dr. Frankenstein, figura essencial da obra, incorpora a imagem do cientista que não leva em consideração os limites éticos humanos e, devido a isso, geralmente ultrapassa o que seria prudente ou são, devido à sua busca pelo desconhecido. Segundo Silva,

O arquétipo do "cientista louco" criado por Shelley a partir da visão romântica de lendas medievais sobre o Judeu Errante, Fausto, a Alquimia, e de personagens de obras literárias como o Satã do Paraíso perdido (1667), do poeta inglês John Milton, se perpetuou em personagens da Ciência Gótica como Dr. Moreau (A ilha do Dr Moreau), de H. G. Wells, Dr. Heidegger ("O experimento do Dr. Heidegger" / 1837), de Nathaniel Hawthorne e Aylmer, e Dr. Rappaccini, também de Hawthorne. Estes dois últimos, personagens respectivamente dos contos "A marca de nascença" e "A filha de Rappaccini", em muito se assemelham ao personagem Avellar. (2008, p. 100)

Assim, Coelho Neto incorpora em sua obra uma personagem que se assemelha à um ícone da FC. Se comparado especificamente com o Dr. Frankenstein, é salutar analisar que Avellar não só ignora os limites éticos, mas o faz com propósito maléfico de matar. Em contrapartida, Dr. Frankenstein é considerado louco por querer ir além dos limites do homem criando um ser. Avellar tem a fonte de sua loucura não só na obsessão científica, mas também na aparição de uma sombra que ele acredita ser a falecida esposa, e que só ele consegue ver: "No dia do enterro, ao voltar do cemitério, notei que, em vez de uma, duas sombras me acompanhavam. Onde quer que eu fosse tinha-as sempre comigo: uma, era a minha; outra, era a da morta. Fiz tudo para livrar-me dela, tudo! Nada consegui" (COELHO NETO, 1926, p. 205). A sombra, que dá nome ao título do conto, só o abandona na delegacia, quando ele confessa o crime cometido. 
Segundo Del Priore, a sombra remeteria ao sobrenatural, sendo um "termo poético que remete à dissolução do corpo no momento da morte" (2014, p. 17). Até então, salvo o estranhamento do bem-estar de Celúta, a narrativa centrava-se majoritariamente na relação homem e ciência. Contudo, em razão do aparecimento da sombra, outras correlações são feitas. Sobre a natureza da sombra, é possível questionar se essa não seria sua consciência, uma vez que ele afirma: "Preso, condenado, perdido para o mundo... Que importa! Mas estou só, a minha consciência já se não projeta diante de mim, a sombra da morta deixoume em paz. Foi melhor assim. Confessei o crime, estou livre" (COELHO NETO, 1926, p. 205). Avellar admite que a consciência dele o perturbava e que isso se foi juntamente com a sombra.

A consciência que se projeta denota também que o marido retornou e o ser fascinado pela experiência desapareceu. Por fim, Avellar mais uma vez expõe sua descrença na credibilidade da ciência, ou seja, na capacidade de ela prover respostas válidas, além da desconfiança em relação a seus profissionais - apesar de ele o ser:

Os médicos, quando não acertam com as enfermidades, escrevem um nome qualquer na certidão de óbito: septicemia, por exemplo. Assim certas verdades quando ultrapassam os limites do conhecimento são chamadas loucuras. Portas de evasão da inteligência humana. (idem, pp. 205-206)

O trecho denota também a incapacidade de os médicos descobrirem a verdadeira situação que levou à morte e, portanto, deixarem um assassino impune. Consequentemente, a causa mortis apontada na biópsia não está errada, mas é incompleta. Este trecho remete a um acontecimento histórico ocorrido antes da Revolta da Vacina, descrito por Sevcenko (2014, p. 8):

Uma mulher morreu no mês de julho, pouco após ter recebido a vacina antivariólica, e o médico legista atribuiu como causa do falecimento um estado de infecção generalizada (septicemia), decorrente da vacinação. A oposição desencadeou de imediato um enorme alarido na Câmara, os jornais vociferaram diatribes contra o governo e a opinião pública robusteceu as suas suspeitas, causando um abalo decisivo na política sanitária oficial. 
A protoficção científica brasileira e sua hibridização através do fantástico: uma análise do conto "A sombra" de Coelho Neto | 429

Assim como o diagnóstico dado pelos médicos a Celúta, essa mulher também foi apontada com septicemia. Posteriormente, devido à repercussão do caso, Osvaldo Cruz realizou outra biópsia e verificou que a vacinação não fora a causa da morte. Observa-se, dessa forma, uma crítica à imprecisão da ciência médica. Ademais, Avellar afirma que as verdades são chamadas de loucura quando não conseguem ser explicadas pelo conhecimento humano, contudo, a loucura seria uma forma da inteligência humana evadir-se, dando a entender que a inteligência humana se perpetua para além do que já é conhecido pelo homem, para além da ciência.

Aqui levanta-se a possibilidade de a visão da sombra ser resultado da loucura do personagem. Este fator, juntamente com o duplo, abre possibilidade para um estudo psicológico da obra. Como dito ao longo da análise, isto se dá devido aos entrelaces de gêneros e figurações na ProtoFC. Haja vista que aproximações com o gênero fantástico podem ser feitas através da sombra. A sombra se caracteriza como o sobrenatural que rompe com a realidade apresentada no conto, não só pela incerteza do que é, mas por ser inexplicável dentro do conto. Seguindo a perspectiva do que seria o Fantástico para Roas, este momento do enredo se aproximaria da estética desse gênero: o rompimento com a realidade concebida tanto no conto, quando na realidade do leitor, ocasionaria o Fantástico.

Esse rompimento seria causado por um fenômeno impossível e incompreensível que subverte os códigos, as certezas que nós designamos para perceber e entender a realidade $(2018$, p. 4). No caso do conto de Coelho Neto, a sombra é este elemento que ultrapassa as noções de realidade de Avellar e é insuperável para ele, sendo incompreensível. Além disso, Roas se contrapõe a Todorov, no que tange à razão para a ocorrência do Fantástico. Segundo Roas, ela não seria causada nem pela dúvida, nem pela incerteza, mas sim pela natureza inexplicável do fenômeno (ROAS, 2018, p. 15). Essa natureza inexplicável é característica da sombra.

Por outro lado, Todorov afirma ser a dúvida que ocasiona o Fantástico e, ao fim do conto, Avellar afirma "julgas-me louco, com certeza. Não, meu amigo. O que te digo é pura verdade" (COELHO NETO, 1927, p. 206). Ou seja, ele estabelece que o que lhe aconteceu fora real. Contudo, no final o narrador afirma: "Haverá juízes que condenem esse pobre louco?" (COELHO NETO, 1927, p. 206), fazendo 
entender, assim, que Avellar é insano. Dessa forma, a dúvida permanece ao fim do conto.

Destarte, é possível perceber que a personagem análoga ao título do conto age como uma vingadora. Vingança esta protagonizada pelo sobrenatural, devido ao assassinato provocado pelo uso da ciência. Observa-se, dessa forma, que quando os meios científicos não conseguem trazer as respostas necessárias, o sobrenatural a ultrapassa, rompendo com a realidade racional.

\section{Considerações Finais}

Apesar das diferentes realidades histórico-culturais, a motivação que levou os escritores brasileiros a incorporar a ciência e o fantástico em suas obras foi a mesma de autores europeus: especular sobre as realizações do homem racional, seja buscando no sobrenatural a fuga, ou explorando os caminhos que a ciência pode proporcionar.

"A sombra" reflete a sociedade do início do século XX, que via crescer a implantação de escolas e institutos, alguns voltados para a área médica e biológica, mas que ainda não tinham as descobertas científicas como algo palpável no seu dia-a-dia. Sociedade que sofreu com a falta de informação e a crença de que o conteúdo da vacina mataria, fato exposto no conto. A ciência, ao final do conto, não só tirou a vida de Celúta, mas também a de Avellar. Além da perturbação em seu casamento e em sua mente, ela o tornou um criminoso e o excluiu do convívio social e do exercício de sua profissão. Infere-se, então, que a ciência é perigosa e não poupa nem aquele que busca desvendá-la e faz uso dela com tal paixão.

Apesar de conter certa percepção das mudanças produzidas pela tecnologia, essa não é baseada em uma compreensão científica, mas permeada de inseguranças. Os acontecimentos não compreendidos são encarados com misticismo, como Avellar via sua mulher como um monstro que carregava a morte. Há uma desconfiança que confronta a visão da Ciência como esperança de desenvolvimento e reforça o ponto de vista da Ciência como uma agente contra o ser humano.

A falta de conhecimento em relação à constituição de uma vacina e seus efeitos levam Avellar a este temor, de forma que ele começa a ver sua esposa como um criadouro de doenças, cuja sobrevivência é inconcebível. Tal reação cerca de misticismo a atmosfera do conto. Este misticismo leva ao sobrenatural, de forma que a narrativa se aproxima também do Fantástico, seja pelo viés da incerteza, seja pela impossibilidade do fenômeno da sombra. O Fantástico surge como uma 
A protoficção científica brasileira e sua hibridização através do fantástico: uma análise do conto "A sombra" de Coelho Neto | 431

forma de escape, uma vez que a racionalidade não conseguiu abarcar a realidade de Avellar.

Os elementos que remetem à $\mathrm{FC}$ presentes no conto são a injeção, enquanto tecnologia; o laboratório; o experimento científico; e o cientista louco. Os elementos fantásticos são o estado de bem-estar de Celúta e a sombra. O uso da injeção levou ao estado de Celúta, o que por sua vez fez Avellar se comportar como um cientista louco e tratá-la como um experimento. A partir de então, o laboratório dele se tornou a cena do crime, motivo pelo qual a sombra passou a persegui-lo. Observa-se como a ProtoFC e o Fantástico estão entrelaçados no conto de Coelho Neto.

Além destes gêneros, a hibridização da ProtoFC permite apontar no conteúdo deste conto a presença de características do gótico e figurações da loucura e do duplo. Em relação às temáticas presentes, Coelho Neto aborda tópicos importantes como o uso de seres humanos em experimentos científicos e a responsabilidade que o médico/cientista possui em relação à vida de outras pessoas. Isto gera uma crítica à ciência "desumana" e ao posicionamento dos médicos em relação ao que lhes é desconhecido.

\section{REFERÊNCIAS}

ARAÚJO, N. S. Ficção Científica Brasileira: Ecofeminismo e PósColonialismo em Umbra de Plínio Cabral. Revista Brasileira de Literatura Comparada. v. 18, n. 28, 2017. Disponível em: <http://revista.abralic.org.br/index.php /revista/article/view/389>. Acesso em: 12/12/2017.

SILVA, A. M. O admirável mundo novo da República Velha: o nascimento da ficção científica brasileira no começo do século XX. 193 f. Tese (Doutorado) - Programa de Pós-Graduação em Ciência da Literatura, Universidade Federal do Rio de Janeiro, 2008. Disponível em <http://www.posciencialit.letras.ufrj.br/images/Posciencialit/td/2008/1 2-alexander meireles_oadmiravel.pdf $>$ Acesso em: 27/08/2016.

ASIMOV, I. No mundo da Ficção Científica. Rio de Janeiro: Livraria Francisco Alves Editora, 1984.

ASIMOV, I. The pre-scientific universe. Asimov's SF Adventure Magazine. New York: Davis Publication. Vol 1. n. 3. Summer, pp. 6-7, 1979.

BELLI, R. C. Ficção Cientifica: um gênero para a ciência. Série essência. v. 4. Blumenau: Edifurb, 2012. 
432 | Thalita Ruth Sousa, Naiara Sales Araújo Santos

COELHO NETO, H. A Sombra. In: . Contos da vida e morte. Porto: Lello \& Irmão, 1927.

DEL PRIORE, M. Do outro lado: A história do sobrenatural e do espiritismo. 1ed. São Paulo: Planeta, 2014.

FIKER, R. Ficção Científica: Ficção, Ciência ou uma Épica da Época? Coleção Universidade Livre. Porto Alegre: L\&PM Editores Ltda, 1985.

LOVECRAFT, H.P. O horror sobrenatural na literatura. Rio de Janeiro: Francisco Alves, 1987.

LÖWY, I. Virus, mosquitos e modernidade: a febre amarela no Brasil entre ciência e política. Rio de Janeiro: Editora FIOCRUZ, 2006.

MESSIAS, A. Todos os monstros da terra: bestiários do cinema e da literatura. São Paulo: EDUC FAPESP, 2016.

MONTEIRO, A. Teologia, colonialismo e ciência e tecnologia/ensino na proto-ficçãocientífica portuguesa (com ou sem política). Alambique: Revista académica de ciencia ficción y fantasia / Jornal acadêmico de ficção científica e fantasía, Vol. 4. pp. 1-30, 2016. Disponível em: <https://scholarcommons.usf.edu/alambique/vol4/iss1/7/> Acesso em: 15/07/2019.

MOTOYAMA, S. Ciência e tecnologia no Brasil - para onde? In:

(Org). Prelúdio para uma história: ciência e tecnologia no Brasil. São Paulo: Editora da Universidade de São Paulo, 2004.

NAGAMINI, M. 1808-1889: ciência e técnica na trilha da liberdade. In: MOTOYAMA, S. (Org). Prelúdio para uma história: ciência e tecnologia no Brasil. São Paulo: Editora da Universidade de São Paulo, 2004.

ROAS, D. Behind the Frontiers of the Real: A Definition of the Fantastic. New York: Palgrave Pivot, 2018.

SCHOEREDER, G. Fiç̧ão Científica. Rio de Janeiro: Livraria Francisco Alves Editora S.A., 1986.

SKORUPA, F. A. Viagem às Letras do Futuro: extratos de bordo da ficção científica brasileira (1947-1975). 256 f. Dissertaçao (Mestrado) - Curitiba, Setor de Ciências Humanas, Letras e Artes, Universidade Federal do Paraná, 2001. Disponível em <http://acervodigital.ufpr.br/bitstream/1884/24261/1/Dissertacao\%20 mestrado\%20Historia-2002.pdf> Acesso em: 28/04/2017.

SMANIOTTO, E. I. Eugenia e Literatura no Brasil: apropriação da ciência e do pensamento social dos eugenistas pelos escritores brasileiros de ficção científica (1922 a 1949). 131 f. Tese (Doutorado) - Faculdade de Filosogia e Ciências, Universidade Estadual Paulista, 2012. Disponível em: $<$ https://repositorio.unesp.br/ 
A protoficção científica brasileira e sua hibridização através do fantástico: uma análise do conto "A sombra" de Coelho Neto | 433

bitstream/handle/11449/100996/smaniotto

_ei_dr_mar.pdf?sequence=1\&isAllowed=y $>$ Acesso em: 28/04/2017.

TAVARES, B. O que é Ficção Científica? São Paulo: Brasiliense, 1986.

TODOROV, T. Introdução à literatura fantástica. São Paulo: Perspectiva, 1975.

Recebido em: 25/08/2019

Aceito em: 15/09/2019 